\title{
Numerical Investigation of Ducted Fuel Injection Strategy for Soot Reduction in Compression Ignition Engine
}

\author{
R. Şener ${ }^{\dagger}$ \\ Department of Automotive Engineering, Batman University, 72100, Batman, Turkey \\ † Corresponding Author Email: ramazan.sener@batman.edu.tr
}

(Received June 8, 2021; accepted October 15, 2021)

\begin{abstract}
The ducted fuel injection strategy is a method that significantly reduces soot emissions in direct injection compression ignition engines. Fuel is injected into the combustion chamber through a duct enhancing the airfuel mixture. It guarantees more efficient combustion and less soot formation by reducing the equivalence ratio at the autoignition zone inside the combustion chamber. The effects of the duct fuel injection on the performance, combustion, and emission of the compression ignition engine were numerically investigated in this study. The duct geometries with varying diameters, lengths, and stand-off distances were examined to find the most appropriate size using an experimentally validated CFD model and detailed soot model. Results show that up to $66.7 \%$ reduction in soot emissions were observed with the usage of the ducted fuel injection strategy compared to conventional diesel combustion. In addition to reducing soot emissions, the ducted fuel injection strategy decreased $\mathrm{CO}$ and $\mathrm{HC}$ emissions by $20.4 \%$ and $7.8 \%$, respectively. While the ducted fuel injection strategy reduces emissions, it does not decrease engine performance; on the contrary, it increases gross IMEP by $0.58 \%$.
\end{abstract}

Keywords: Ducted Fuel Injection; Leaner lifted flame combustion; CFD; Combustion; Soot.

\section{NOMENCLATURE}

$\begin{array}{llll}\text { AMR } & \text { Adaptive Mesh Refinement } & \text { LNT } & \text { Lean NOx-trap } \\ \text { ATDC } & \text { After-Top Dead Center } & \text { LTC } & \text { Low-Temperature Combustion } \\ \text { BDC } & \text { Bottom Dead Center } & \text { NOx } & \text { Nitrogen oxides } \\ \text { BTDC } & \text { Before-Top Dead Center } & \text { NTC } & \text { No Time Counter } \\ \text { CA } & \text { Crank Angle } & \mathrm{O}_{2} & \text { Oxygen } \\ \text { CA50 } & \text { mass fraction burned of 50\% } & \text { PPC } & \text { Partially Premixed Combustion } \\ \text { CA90 } & \text { mass fraction burned of 90\% } & \text { PSDF } & \text { Particle Size Distribution Function } \\ \text { CDC } & \text { Conventional Diesel Combustion } & \text { PSM } & \text { Particle Size Mimic } \\ \text { CFD } & \text { Computational Fluid Dynamics } & \text { RANS } & \text { Reynold Averaged Navier Stokes } \\ \text { CI } & \text { Compression Ignition } & \text { RNG } & \text { Renormalization Group } \\ \text { CO2 } & \text { carbon dioxide } & \text { SCR } & \text { Selective Catalytic Reduction } \\ \text { CO } & \text { carbon monoxide } & \text { SOI } & \text { Start of Injection } \\ \text { CVCV } & \text { Constant Volume Combustion Vessel } & \text { TDC } & \text { Top Dead Center } \\ \text { DFI } & \text { Ducted Fuel Injection } & & \\ \text { DSMC } & \text { Direct Simulation Monte Carlo } & & \\ \text { EGR } & \text { Exhaust Gas Recirculation } & \text { Notations } \\ \text { EVO } & \text { Exhaust Valve Opening } & \varepsilon & \text { turbulent dissipation rate } \\ \text { HC } & \text { Hydrocarbon } & \mathrm{k} & \text { turbulent kinetic energy } \\ \text { HCCI } & \text { Homogeneous Charge Compression } & \mu & \text { dynamic viscosity } \\ & \text { Ignition } & \rho & \text { fluid density } \\ \text { HTPV } & \text { High-Temperature-Pressure Vessel } & \mathrm{Q} & \text { rates of particles } \\ \text { IMEP } & \text { Indicated Mean Eff ective Pressure } & \mathrm{r} & \text { reactions rate constants } \\ \text { IVC } & \text { Intake Valve Closing } & \mathrm{S} & \text { source term } \\ \text { KH-RT } & \text { Kelvin-Helmholtz Rayleigh-Taylor } & \mathrm{SC} & \text { Schmidt number } \\ \text { LLFC } & \text { Leaner Lifted Flame Combustion } & \mathrm{T} & \text { temperature } \\ & & & \end{array}$




\section{INTRODUCTION}

Compression ignition (CI) engines are widely used for their high power density, high efficiency, and reliability and will be used for decades (Reitz et al. 2020; Zhu et al. 2005). These engines emit soot and $\mathrm{NO}_{\mathrm{x}}$ emissions because of high-temperature combustion processes, and fuel-rich zones during the mixing-controlled combustion processes (Pickett 2005; Vadivel and Periyasamy 2020). However, exhaust emissions adversely affect the ecology, atmosphere, and human health (Walters 2010). Thus, these exhaust emissions must be reduced both for environmental concerns and to meet increasingly stringent emission standards (Gandhi et al. 2003; Gugulothu and Reddy 2016; Knecht, 2008).

There are two main approaches to controlling exhaust emissions. One of them is to reduce emissions by improving the combustion process (Fajri et al. 2019; Mohan et al. 2013), and the other approach is to prevent the release of harmful gases from the exhaust using an aftertreatment system (Brijesh and Sreedhara 2013). Exhaust aftertreatment methods for instance lean $\mathrm{NO}_{\mathrm{x}}$-trap (LNT) and selective catalytic reduction (SCR) significantly increase the system complexity, weight, and cost (Lao et al. 2020; Praveena and Martin 2018). Emission reduction methods are expected to be low-cost.

Combustion strategies such as low-temperature combustion (LTC), homogeneous charge compression ignition (HCCI), and partially premixed combustion (PPC) are applied so that the engine could produce low soot and $\mathrm{NO}_{\mathrm{x}}$ emission (An et al. 2018; Mathivanan et al. 2019). However, these methods should be coped with some difficulties such as controlling combustion with a knock, high level of noise, weak cold start capability, and phase control (Calam et al. 2019). The engine can only operate with high efficiency in a limited operating range (Bakhshan and Shadaei 2013; Mofijur et al. 2019).

The combustion inside the cylinder must occur at maximum efficiency at a wide operating range. So as to achieve this condition, the fuel and air in the cylinder should be mixed well, and complete combustion should also occur at a lower temperature to inhibit $\mathrm{NO}_{\mathrm{x}}$ formation. The combustion chamber optimization, the usage of a new type of swirl piston bowl, the optimization of valve timings, and injection parameters can improve combustion efficiency as well as reduce emissions (Sener et al. 2020; Şener and Gül 2021). However, in these methods, the emission reduction is not enough and is also limited by the soot-NOx tradeoff (Deb et al. 2015; Zhou et al. 2014).

One of the new methods for more efficient combustion is leaner lifted flame combustion (LLFC) which enhances the fuel-air mixing (Polonowski et al. 2011). This method, which has a mixing-controlled combustion strategy, promises to produce almost soot-free emissions when the equivalence ratio in the lift-off length is maintained at less than about two (Gehmlich et al. 2016). It is recommended to use fuels with higher oxygen content in this method for more effectiveness. In addition, nitrogen oxides emissions can be reduced simultaneously by using exhaust gas recirculation (EGR) to decrease the in-cylinder temperature.

The maximum load limit of the LLFC strategy can be expanded by enhancing the charge-gas mixture (Gehmlich et al. 2016). The ducted fuel injection (DFI) method was firstly proposed by Mueller to improve air-fuel mixing upstream of the lift-off length with a duct (Mueller et al. 2017). The fuel is passed through the duct that places a gap downstream of the fuel injector hole. Thus, the equivalence ratio is lowered before the combustion (Mueller et al. 2017). DFI method significantly reduces soot emissions compared to conventional diesel combustion (CDC). The fluid radial velocity in the duct is zero, which reduces the radial energy loss, allowing the fuel spray to mix better with the air flowing through the duct.

Mueller et al. introduced the DFI method as a mixing-enhanced method to the literature. They have performed experiments in a constant-volume combustion vessel (CVCV) to investigate the DFI strategy. The experimental results show that considerably lower soot incandescence was observed from DFI than CDC over wide charge-gas conditions (Mueller et al. 2017). Gehmlich et al. performed experimental studies in a CVCV to examine the effect of performance of the geometrical parameters of the tube in DFI strategy on the combustion process and soot incandescence. They investigated the duct diameter, length, and stand-off distance, inlet, and outlet shapes on the lift-off length, penetration, ignition delay, total pressure rise, and soot mass. They found that when the stand-off distance decreases, the ignition delay slightly increases. They determined that the small duct size according to the packaging of the engine is also effective in lowering the soot emissions by 35 $100 \%$ (Gehmlich et al. 2018). Fitzgerald et al. studied the effect of DFI strategy on soot emission using a high-temperature-pressure vessel (HTPV) with engine-like conditions (60-120 bar, 800-950 $\mathrm{K})$. They carried out experimental and simulation studies on varying duct diameters. Soot luminosity has decreased by as much as 50\% under high pressure and temperature conditions (Fitzgerald et al. 2018). Nilsen et al. investigated the effects of diesel blended with $30 \%$ aromatics on DFI strategy in the CVCV. It has been determined that the DFI method reduces soot emission and breaks the soot$\mathrm{NO}_{\mathrm{x}}$ trade-off (Nilsen et al. 2019). Li et al. examined the effect of the DFI method using a onehole nozzle in the CVCV. They observed that the fuel spreads better and the spray cone angle increases by $4^{\circ}$ using the duct. When the fuel spray leaves the duct, it spreads rapidly, which increases the mixing process. In the DFI strategy, spray penetration increases at high injection pressures $(\mathrm{Li}$ et al. 2019). Nilsen et al. investigated the influence of the DFI strategy experimentally at low and high loads compared with conventional diesel combustion. They found that soot emission 
considerably was reduced by using the DFI method with 4-orifice under all operating conditions (Nilsen et al. 2020). Svensson et al. studied the influence of the DFI method with varying duct diameter and length by using a one-hole fuel injector with an injection pressure of $200-250 \mathrm{MPa}$ in the hightemperature-pressure vessel. They recognized that the lower soot emission is achieved with a longer ignition delay period and shorter combustion duration. The duct including a $2 \mathrm{~mm}$ diameter and 8 $\mathrm{mm}$ length caused a significant reduction in soot emissions (Svensson and Martin 2019). Li et al. used the Mie-scattering optical method to compare DFI and CDC with a single-hole injector. Experiments were carried out with different ambient pressures and injection pressures. They found that the advantages of the DFI strategy become more evident with the high ambient temperature and high-pressure injector ( $\mathrm{Li}$ et al. 2020). Liu et al. simulated the DFI by using the reaction of $\mathrm{n}$-dodecane using four different reduced chemical mechanisms in the computational fluid dynamics (CFD) model and validated with experiments. They also suggested a post-processing method to examine the feature of the detailed combustion. According to the findings, the DFI strategy provides a longer lift-off length and ignition delay than CDC. With the DFI method, a noticeably higher low-temperature heat release zone and a lower high-temperature heat release zone have been obtained, which reduces the tendency for soot formation (Liu et al. 2020). Li et al. investigated the influence of the stand-off distance and duct diameter on the DFI strategy. The results indicated that a duct with a smaller diameter has better spray diffusion, more extended spray penetration, and wider cone angle compared to a duct with a larger diameter (Li et al. 2021).

As can be understood from the studies presented above, soot emissions are dramatically reduced by the DFI method. This method breaks the soot-NOx trade-off. However, since this method is still new, it needs further development. The DFI strategy can be adapted to the engine with maximum effectiveness by optimizing the duct geometry according to the combustion chamber and injector. In addition, it is necessary to understand the soot formation mechanism of the DFI. There are a few numerical studies about this topic in the literature. The numerical models with validated experiments can promote an understanding of the mechanism underlying soot formation of the DFI method. However, there is no numerical study about the implementation of the DFI strategy to the CI engine. This study focuses on the adaptation of the DFI method to a heavy-duty CI engine. The CFD simulation has been performed using the detailed soot mechanism to compare the differences between CDC and DFI. It has been investigated the influence of the duct geometric parameters on performance, combustion, and emission of the $\mathrm{CI}$ engine.

The duct geometries have been generated in accordance with the combustion chamber of the CI engine. The duct is adapted to the injector according to the spray angle. The $\delta$ geometry proposed by
Gehmlich et al. (Gehmlich et al. 2018) was used as the duct shape. It is shown schematically in Fig. 1 with the parameters of the duct geometry, i.e., G (stand-off distance or axial gap from the duct to the injector), D (the inner duct diameter), and $\mathrm{L}$ (the duct length). The nomenclature used herein is D [mm] x L [mm] - G [mm] to express the different duct configurations used. For example, 2 x $8-4.8$ refers to $2 \mathrm{~mm}$ duct diameter, $8 \mathrm{~mm}$ length, and 4.8 $\mathrm{mm}$ stand-off distance. The wall thickness of the duct is $1 \mathrm{~mm}$ for all DFI cases.

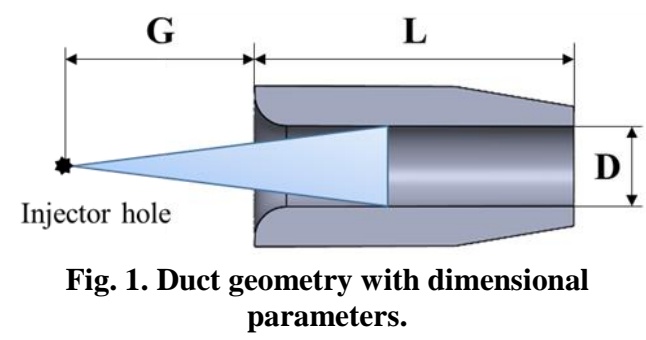

\section{MethodologY}

\subsection{Numerical setup}

The numerical studies were carried out using Converge v2.4 commercial CFD solver for solutions of three-dimensional Reynolds-averaged Navier-Stokes (RANS) equations (Richards et al. 2019). The Renormalization Group (RNG) k- $\varepsilon$ model was adopted to account for turbulence modeling in the computational domain (Han and Reitz 1995; Yakhot and Orszag, 1986). This model is widely used in the literature for solution accuracy, simplicity, and effectiveness (Demirkesen et al. 2020).

The droplet parcels are defined to the region at the injector location where a specified size and number in order to calculate the spray in a simulation. The parcels represent the same set of droplets (such as the same radius, speed, temperature, etc.) and they are used to represent the fuel spray volume statistically. Using the droplet parcel concept significantly reduces the calculation time of a spraycontaining simulation (Richards et al. 2019). The identification of the spray is a process, and the solution is achieved using specific models at each stage. In this study, solid cone injection is defined for fuel injection and a total number of parcels was selected as 50,000. The Kelvin-Helmholtz / Rayleigh-Taylor (KH-RT) model for the spray breakup and atomization has been used (Beale and Reitz 1999). Mechanical relationships for the definition of liquid and gas motion are combined with linearized hydrodynamic equations. The result is obtained by converting the equation of motion into the flow and potential function (Reitz 1987).

The wall heat transfer was simulated using the O'Rourke and Amsden model (Amsden 1997). This model generally provides the most reliable results for engine applications (Babayev et al. 2021). The Rebound/Slide model was used for the spray-wall 
interaction during the fuel injection (Manuel et al. 1991).

The No Time Counter (NTC) scheme was selected as a collision model (Schmidt and Rutland 2000). The NTC technique depends on the Direct Simulation Monte Carlo (DSMC) gas dynamics. This technique is obtained from the basic probability assignment without assumptions. The cell size in the basic probability model should be small enough that spatial changes in spray quantities are negligible. Frossling evaporating model is used to clarify the effect of the alteration on the discrete phase whenever the liquid parcels reach the critical or boiling temperature (Sherwood 1993).

The SAGE (detailed transient chemistry solver) combustion model calculates the rates of reaction and species concentrations within each time step and each cell using CHEMKIN-formatted input files (Senecal et al. 2003). The reaction mechanism used in this study was developed by Zeuch et al. (Zeuch et al. 2008). This skeletal mechanism, which contained 121 species - 593 reactions were derived from two mechanisms as 249 species - 2500 reactions and 550 species - 5000 reactions (Ahmed et al. 2007; Curran et al. 1998).

Thermal NOx mechanism is dependent on the temperature of the reaction (Yangaz et al. 2019). If the temperature increases to the specific value, $\mathrm{NOx}$ formation occurs. The expanded Zeldovich model is used to calculate NO formation. This mechanism forms of the below reactions (Heywood 1988):

$$
\begin{aligned}
& O+N_{2} \Leftrightarrow N O+N \\
& N+O_{2} \Leftrightarrow N O+O \\
& N+O H \Leftrightarrow N O+H
\end{aligned}
$$

The reactions rate constants for Eqs. 1, 2, and 3 $\left(\mathrm{cm}^{3} / \mathrm{mol} \cdot \mathrm{s}\right)$ :

$$
\begin{aligned}
& r_{1, f}=7.6 \times 10^{13} e^{\left(\frac{-38000}{T}\right)} \\
& r_{1, r}=1.6 \times 10^{13} \\
& r_{2, f}=6.4 \times 10^{9} \cdot T \cdot e^{\left(\frac{-3150}{T}\right)} \\
& r_{2, r}=1.5 \times 10^{9} \cdot T \cdot e^{\left(\frac{-19500}{T}\right)} \\
& r_{3, f}=4.1 \times 10^{13} \\
& r_{3, r}=2.0 \times 10^{14} \cdot e^{\left(\frac{-23650}{T}\right)}
\end{aligned}
$$

where the subscript $f$ denotes a forward reaction, and the subscript $r$ denotes a reverse reaction.

Prompt $\mathrm{NO}_{\mathrm{X}}$ mechanism is completely related to the hydrocarbon combustion chemistry. NOx occurs in fuel-rich and low-temperature zones where the concentration of oxygen is high (De Soete 1975; Richards et al. 2019).

A particle size mimic (PSM) detail soot model was used with the condensation sub-model to simulate the soot formation (Kumar and Ramkrishna 1996; Wen et al. 2005). This model reveals the particle size distribution function for each cell with the discrete sectional method. The particle size distribution function (PSDF) defines the properties of soot particles. It can be calculated by solving the partial differential equations for the number density of all sections (Ibrahim et al. 2017). By applying these formulas, each section is solved as a global transport passive:

$$
\begin{gathered}
\frac{D\left(\frac{\dot{Q}_{i}}{\rho}\right)}{D t}=\nabla\left(\frac{\mu}{S C} \nabla\left(\frac{\dot{Q}_{i}}{\rho}\right)\right)+\dot{S}_{\dot{Q}_{i}} \\
\dot{S}_{\dot{Q}_{i}}=\Delta \dot{Q}_{i, p i}+\Delta \dot{Q}_{i, c o n}+\Delta \dot{Q}_{i, s g} \\
+\Delta \dot{Q}_{i, \text { ox }}+\Delta \dot{Q}_{i, \text { coag }}
\end{gathered}
$$

$\hat{S}_{Q_{i}}$ is the source term for each section and SC is the Schmidt number. The combustion model solves the source terms of the species and sections with a twoway coupling method thence soot generation affects the gas phase and heat release of the model. Submodels used in the CFD simulations were listed in Table 1.

Table 1 Simulation sub-models

\begin{tabular}{|l|l|}
\hline Turbulence & RNG k- $\varepsilon$ model \\
\hline Spray Breakup & KH + RT model \\
\hline Evaporation & Frossling model \\
\hline $\begin{array}{l}\text { Spray-wall } \\
\text { interaction }\end{array}$ & Rebound/Slide model \\
\hline Collision & NTC model \\
\hline Combustion & $\begin{array}{l}\text { SAGE chemical kinetics } \\
\text { solver }\end{array}$ \\
\hline $\begin{array}{l}\text { Reaction } \\
\text { mechanism }\end{array}$ & 121 species, 593 reactions \\
\hline NOx & $\begin{array}{l}\text { Extended Zeldovich } \\
\text { mechanism }\end{array}$ \\
\hline Detailed soot & Particle Size Mimic model \\
\hline
\end{tabular}

\subsection{Experimental Validation}

The experimental results of the Caterpillar ${ }^{\circledR} 3401$ single-cylinder direct-injection heavy-duty compression-ignition engine were obtained from conducted experiments in the University of Wisconsin Madison, Engine Research Center to validate the engine model (Curtis et al. 1995; Senecal et al. 2007). Combustion analyses were performed at $75 \%$ load and $1600 \mathrm{rev} / \mathrm{min}$ operating conditions. The engine and injector specifications are summarized in Table 2. The fuel injector is a common rail with $90 \mathrm{MPa}$ injection pressure. The 
start of injection (SOI) is $9^{\circ} \mathrm{BTDC}$ and the injection duration is $21^{\circ} \mathrm{CA}$.

Table 2 Caterpillar SCOTE 3401 test engine specifications

\begin{tabular}{|l|l|}
\hline Cylinder bore & $137.6 \mathrm{~mm}$ \\
\hline Stroke & $165.1 \mathrm{~mm}$ \\
\hline Crank offset & $0.0 \mathrm{~mm}$ \\
\hline Connecting rod length & $261.6 \mathrm{~mm}$ \\
\hline IVC & $147.0^{\circ} \mathrm{BTDC}$ \\
\hline EVO & $135.0^{\circ} \mathrm{ATDC}$ \\
\hline Compression ratio & $15.95: 1$ \\
\hline Initial pressure & $197.0 \mathrm{kPa}$ \\
\hline Initial temperature & $355.0 \mathrm{~K}$ \\
\hline Injection pressure & $90 \mathrm{MPa}$ \\
\hline Injector hole diameter & $0.259 \mathrm{~mm} \times 6$ \\
\hline SOI & $9^{\circ} \mathrm{BTDC}$ \\
\hline Injection duration & $21^{\circ} \mathrm{CA}$ \\
\hline Injector spray angle & $125 \mathrm{deg}$. \\
\hline Fuel mass injected & $162.5 \mathrm{mg} / \mathrm{cycle}$ \\
\hline
\end{tabular}

The CFD model was developed in order to validate against the test engine. Because of six equally injector orifices, the test engine was simulated as a $60^{\circ}$ sector mesh with periodic boundaries. The model has performed at the closed volume from the intake valve closing (IVC) to the exhaust valve opening (EVO). The initial mixture (air + EGR) was assumed to be uniform, and the swirl profile was taken as 3.11 inside the cylinder. Initial conditions were chosen in accordance with experimental results. Initial pressure and temperature were $197.0 \mathrm{kPa}$ and $355.0 \mathrm{~K}$. The injection pressure was set to $90 \mathrm{MPa}$ and the compression ratio to 16 . The piston, cylinder head, and liner wall temperatures were kept at $553 \mathrm{~K}, 523$ $\mathrm{K}$, and $433 \mathrm{~K}$, respectively. The duct temperature was defined as $523 \mathrm{~K}$ for all DFI cases.

The computational domains of the CDC and DFI case $(2 \times 8-4.8$ duct $)$ were illustrated in Fig. 2. All major geometrical dimensions of the test engine such as cylinder bore, piston bowl volume, stroke, and squish height were completely generated in the computational domain. The duct geometries were implemented in the combustion chamber according to the spray alignment. For different duct geometries, only the duct was changed, but all other engine parameters were kept constant. Once the duct geometries were added, the compression ratio was not calibrated with the baseline CDC case. However, the compression ratio of the DFI cases is not considerably changed. While the compression ratio of the $\mathrm{CDC}$ is 15.9493 , the compression ratio of DFI is 15.9857 for $2 \times 8-3.2$ duct, 15.9857 for $2 \times 8-4.8$ duct, 15.998 for $3 \times 8-4.8$ duct, 15.9795 for $15 \times 8-4.8$ duct, 16.0103 for $1.5 \times 16-3.2$ duct, and 16.0228 for $2 \times 16-3.2$ duct. The change of the compression ratio is between 0.0735 and 0.0302 .

The model calibration was performed by comparing simulation and experimental data of pressure, rate of heat release, and exhaust emissions (Fig. 3). The

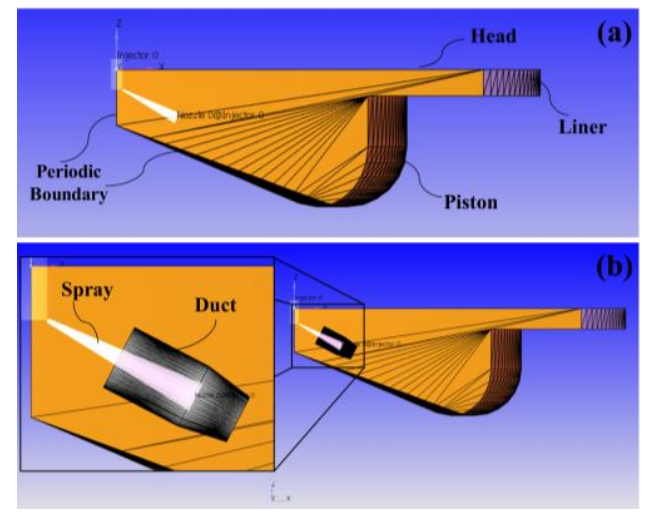

Fig. 2. Computational domains of a) CDC and b) DFI case.
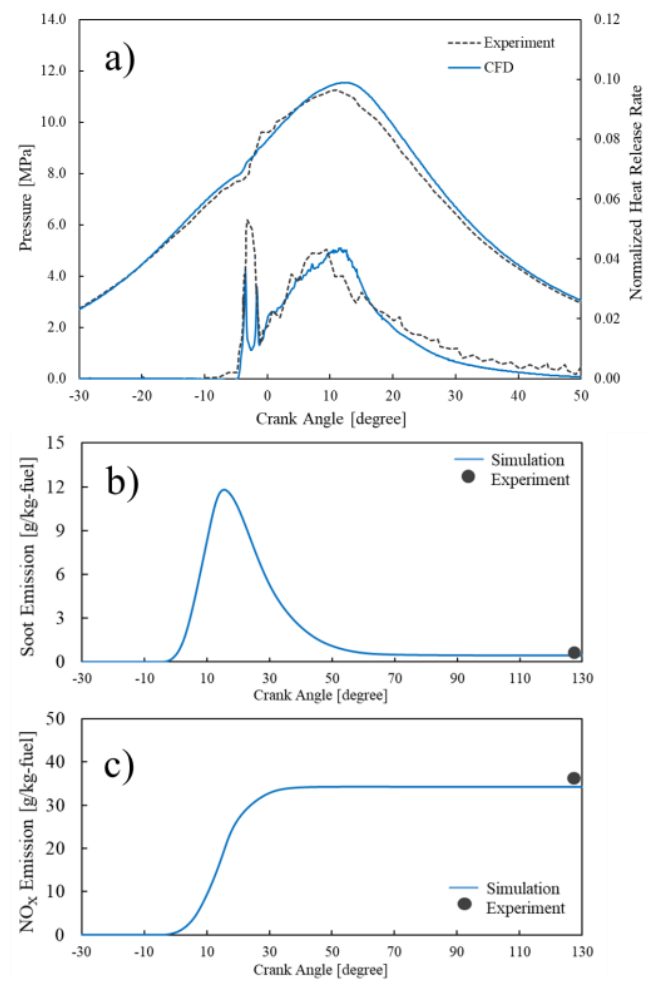

Fig. 3. Comparison of experiment and simulation for a) pressure, b) soot, and c) NOx.

in-cylinder pressure trace of the experimental data and the simulation difference does not exceed $6.88 \%$ and the average deviation is $2.42 \%$ (Fig. $3(\mathrm{a})$ ). The average relative error of the experiment and simulation is $8.50 \%$ for soot emission and $4.63 \%$ for $\mathrm{NOx}$ emission (Figs. 3(b) and 3(c)). These values show that the simulation results are compatible with the experimental values. All comparisons between the simulation and reported experimental data are indicating good qualitative agreement and are within the acceptable range.

\subsection{Mesh Independency}

The mesh size is one of the most critical parameters dealing with CFD simulations (Galindo et al. 2013). 
The mesh structure should be fine enough in terms of cell count and size to faithfully reproduce the geometry. The mesh independence study is based on the searching of the solution with different mesh sizes. A structured and orthogonal mesh based on user-defined control parameters was used for the simulations in this study. Since it is observed that the discretization error decreases with the finer grids, the most appropriate cell size is tried to be determined by performing mesh independence analysis. As with the usual procedure, the mesh independence analysis is based on the approach of using increasingly fine mesh until the solution variation between two consecutive cases is small enough. The CPU time should not increase too much with the small improvement in solution accuracy. The numerical setup described in the previous section was also used in the mesh independence analysis.

A 1/6th of the computational domain as sector mesh is used to reduce CPU time considering that the diesel injector has six nozzle orifices. This method is widely used in the literature for internal combustion engine applications (Babayev et al. 2021; Turkcan et al. 2015; Yousefi et al. 2020). Adaptive mesh refinement (AMR) based on fields of velocity and temperature was applied in this study to refine the mesh size on the zones in which high species concentration and turbulent flame front gradients. Fixed embedding of local grid refinement was adopted to accurately resolve temperature gradients and velocity for cylinder head, piston, cylinder wall as well as fuel spray location. The numerical setup was the same during the mesh independence studies except for base grid size. Three different mesh sizes of $1 \mathrm{~mm}, 1.4 \mathrm{~mm}$, and 2 $\mathrm{mm}$ base grid cell size and $0.25 \mathrm{~mm}, 0.35 \mathrm{~mm}$, and $0.5 \mathrm{~mm}$ minimum grid size were used as fine, medium, and coarse, respectively.

The cylinder-averaged pressure of three different mesh sizes followed a similar trend (Fig. 4). The fine mesh predicted the maximum pressure values more precisely than the medium and coarse mesh whereas it increased CPU time. The coarse mesh overestimated the maximum pressure, moreover, it had inconsistency in the auto-ignition region, and around the top dead center. The medium-mesh size produced satisfactory results in terms of both solution accuracy and computational time. Thus, the medium mesh with a base grid size of $1.4 \mathrm{~mm}$ was adopted with two levels of AMR, reducing the minimum grid size up to $0.35 \mathrm{~mm}$ in critical regions. The total number of cells during the transient simulations reached up to $8 \cdot 10^{+5}$ when AMR and fixed embedding were applied.

\section{RESUlt AND DISCUSSIONS}

The duct geometry was adopted to the baseline engine for the DFI strategy. Moreover, the different duct geometries were simulated under the same operating conditions to investigate varying geometrical duct parameters, which in three diameters, two lengths, and two stand-off distances

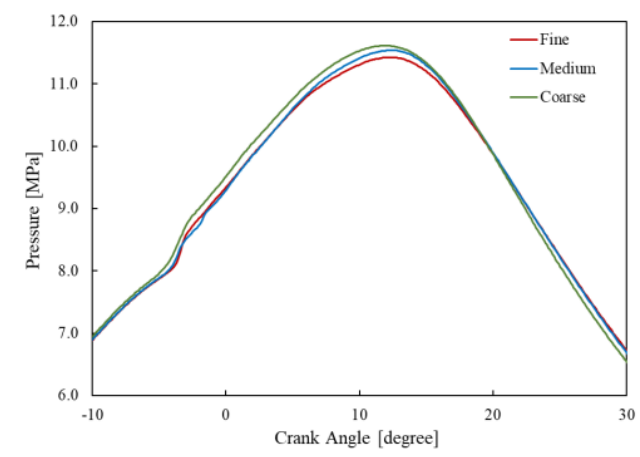

Fig. 4. Comparison of in-cylinder pressure traces of three different mesh sizes.

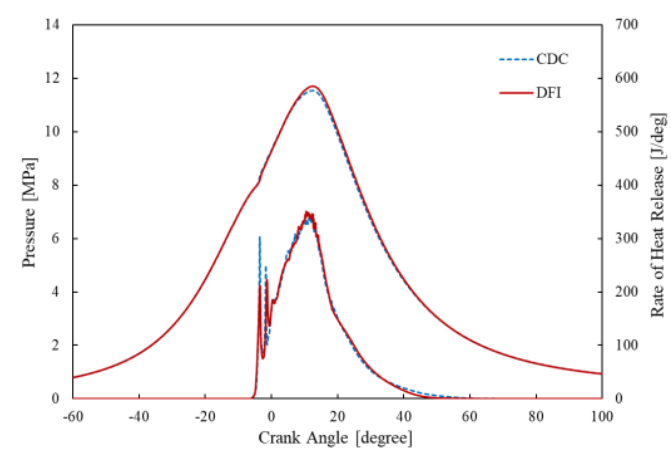

Fig. 5. Comparison of in-cylinder pressure traces for the CDC and the DFI case.

(Table 3). Six different duct designs in total were generated such as $2 \times 8-3.2$ duct, $2 \times 8-4.8$ duct, $2 \times 16$ 3.2 duct, $3 \times 8-4.8$ duct, $1.5 \times 16-3.2$ duct, and $1.5 \times 8$ 4.8 duct. The influence of the related parameter was examined by keeping two of the three geometric parameters constant. Results were compared according to in-cylinder pressure, heat release rate, ignition delay, CA50, CA90, gross IMEP, thermal efficiency, as well as soot, $\mathrm{NO}_{\mathrm{x}}, \mathrm{CO}$, and $\mathrm{HC}$ emission values.

Table 3 Duct configurations

\begin{tabular}{|l|c|c|c|c|}
\hline Parameter & unit & \multicolumn{3}{|c|}{ value } \\
\hline Diameter & $\mathrm{mm}$ & 1.5 & 2.0 & 3.0 \\
\hline Length & $\mathrm{mm}$ & 8 & 16 & \\
\hline Stand-off distance & $\mathrm{mm}$ & 3.2 & 4.8 & \\
\hline
\end{tabular}

\subsection{Effect of the ducted fuel injection}

The DFI strategy has significantly improved charge-gas mixing. CDC and DFI strategy with 2x8-4.8 has been compared in Figs. 5-11. As shown in Fig. 5, the pressure has increased slightly with the DFI approach. DFI enhances the vaporized fuel mass during the injection while the duct delays slightly the evaporation process, but then, it increases the evaporation rate (Fig. 6). Figure 7 illustrates the distribution of equivalence ratio inside the cylinder 


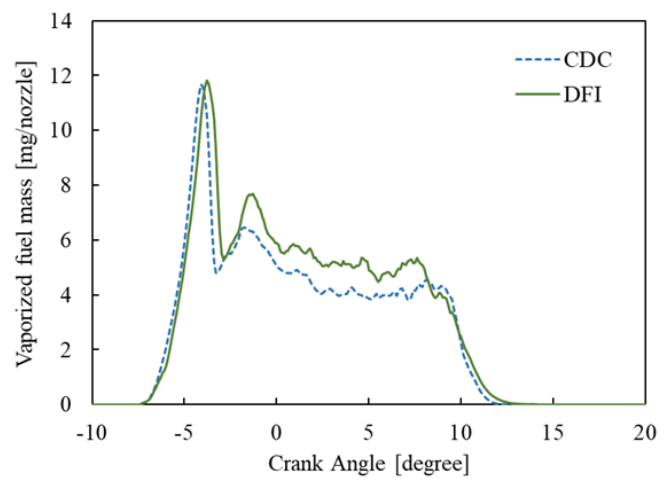

Fig. 6. Comparison of vaporized fuel mass during the injection for the CDC and the DFI case.

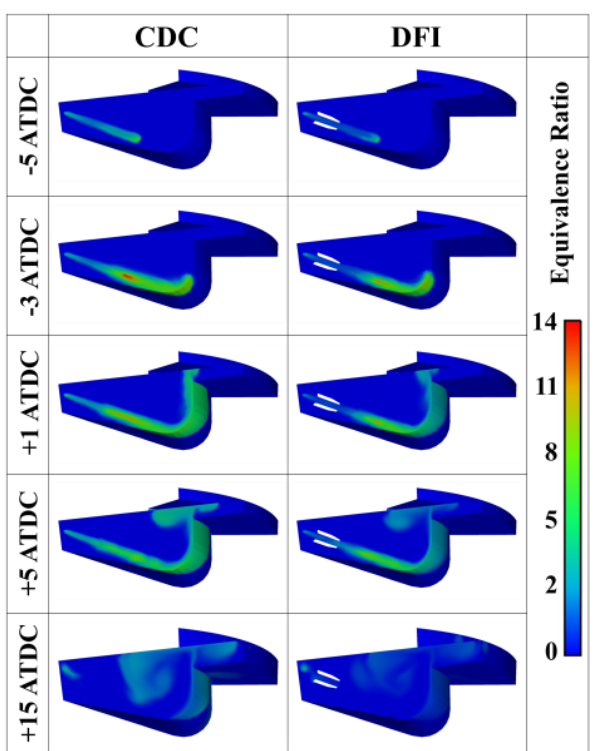

Fig. 7. Equivalence ratio distributions for the CDC and the DFI case at different crank angles.

at $-5^{\circ},-3^{\circ},+1^{\circ},+5^{\circ}$, and $+15^{\circ}$ ATDC for CDC and DFI. Since the DFI method enhances air-fuel mixing, the equivalence ratio distributes more uniformly than CDC especially at $+15^{\circ}$ ATDC around the auto-ignition region. This method decreases the equivalence ratio around the lift-off length. As a consequence, the DFI enlarges the spray penetration, the concentration of fuel on the piston bowl increases.

The soot concentration inside the cylinder decreases with the DFI method. Significantly less soot emission was formed while the piston reaches from the -3 ATDC to the BDC (Fig. 8). Because of the homogenous distribution of the equivalence ratio in the cylinder, a relatively uniform temperature occurs from combustion starts to the EVO (Fig. 9). It is seen that the mixture enhanced with the usage of the duct. DFI method also affects velocity vectors.

DFI increases the velocity vectors at a longer distance in the cylinder, due to the higher spray penetration (Fig. 10). Compared to CDC, DFI cases produce significantly longer, leaner, and faster spray. DFI with $2 \times 8-4.8$ duct reduces the soot, $\mathrm{CO}$, and $\mathrm{HC}$ emission formation (Fig. 11).

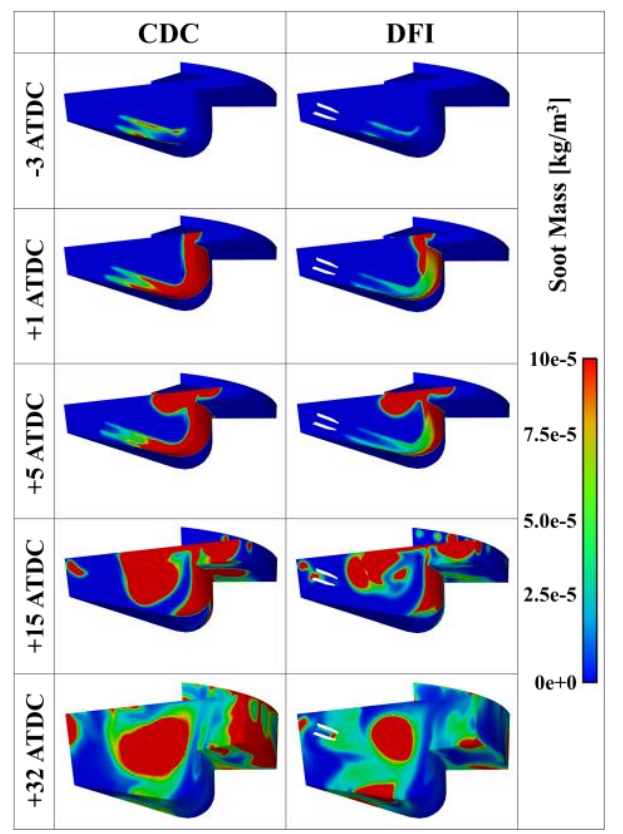

Fig. 8. Soot distributions for the $\mathrm{CDC}$ and the DFI case at different crank angles.

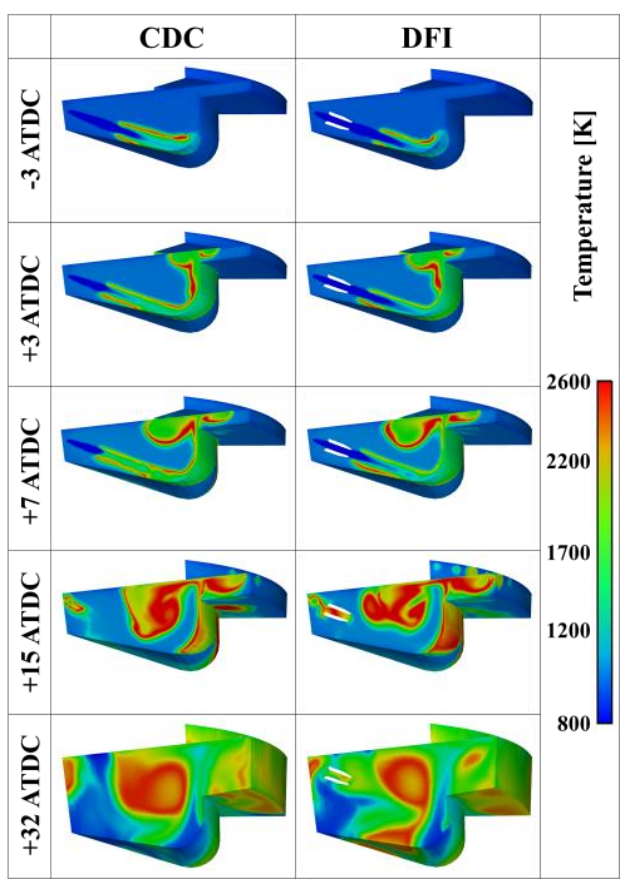

Fig. 9. Temperature distributions for the CDC and the DFI case at different crank angles.

Soot emission reduction reaches $67 \%$ with DFI, whereas $\mathrm{HC}$ and $\mathrm{CO}$ emission reductions are only $8 \%$ and $20 \%$, respectively (Fig. 11(a, c, d)). However, it is observed that NOx emission increases (Fig. 11(b)). 


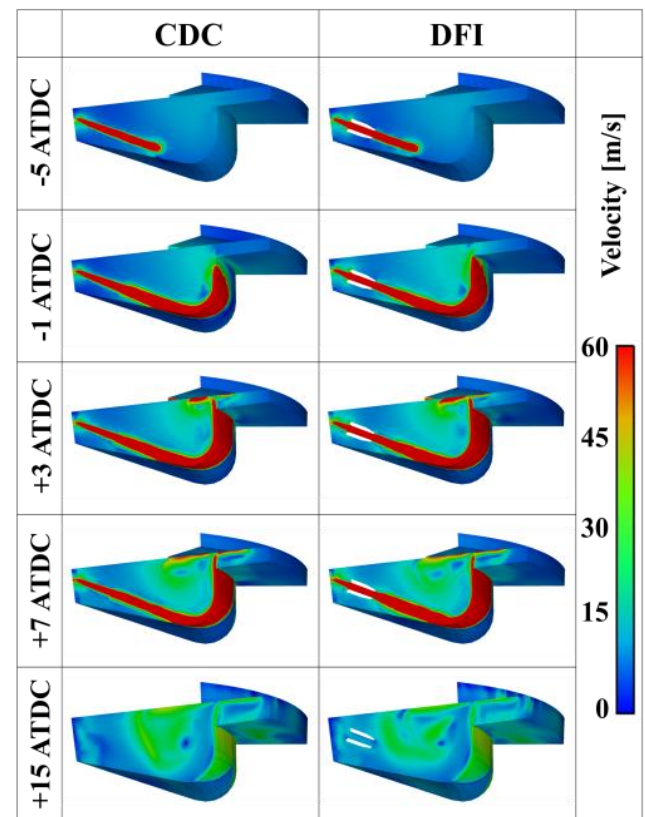

Fig. 10. Velocity distributions for the CDC and the DFI case at different crank angles.

\subsection{Effect of the duct inner diameter}

The effects of duct inner diameters have been studied keeping other parameters constant such as the duct length and the axial distance. The incylinder pressure curve of $1.5 \times 8-4.8$ duct, $2 \times 8-4.8$ duct, and $3 \times 8-4.8$ duct and CDC is shown in Fig. 12. The in-cylinder pressure has increased slightly with the DFI approach. The highest rise was noticed with the $2 \times 8-4.8$ duct. Heat release during premixed combustion decreases, whereas heat release during mixing-controlled combustion increases with DFI (Fig. 13). Consequently, this situation significantly affects the formation of soot.

It is seen that the ignition delay is prolonged with the DFI. The duct with a diameter of $2 \mathrm{~mm}$ has the longest ignition delay. The crank angle at which $50 \%$ and $90 \%$ of the fuel is burned decreases with DFI. In addition, with DFI, the crank angle at which the maximum pressure to be acquired increases compared to CDC. As a result, the gross IMEP and thermal efficiency increase with DFI (Fig. 14). The 2x8-4.8 duct has a longer ignition delay and shorter CA50 and CA90 than the other DFI and CDC cases.

Soot formation decreases considerably with the DFI approach. While the soot emission decreased along with the usage of the ducts with different diameters, the highest soot reduction was achieved with the $2 \times 8-4.8$ duct at a rate of $66.7 \%$ (Fig. 15). $\mathrm{HC}$ and $\mathrm{CO}$ emissions also decreased by $2 \times 8-4.8$ duct by $20.4 \%$ and $7.8 \%$, respectively. NOx emission increased by $10.1 \%, 15.1 \%$ and $6.6 \%$ in $1.5 \times 8-4.8$ duct, $2 \times 8-4.8$ duct and $3 \times 8-4.8$ duct, respectively. These values can be reduced by using EGR.
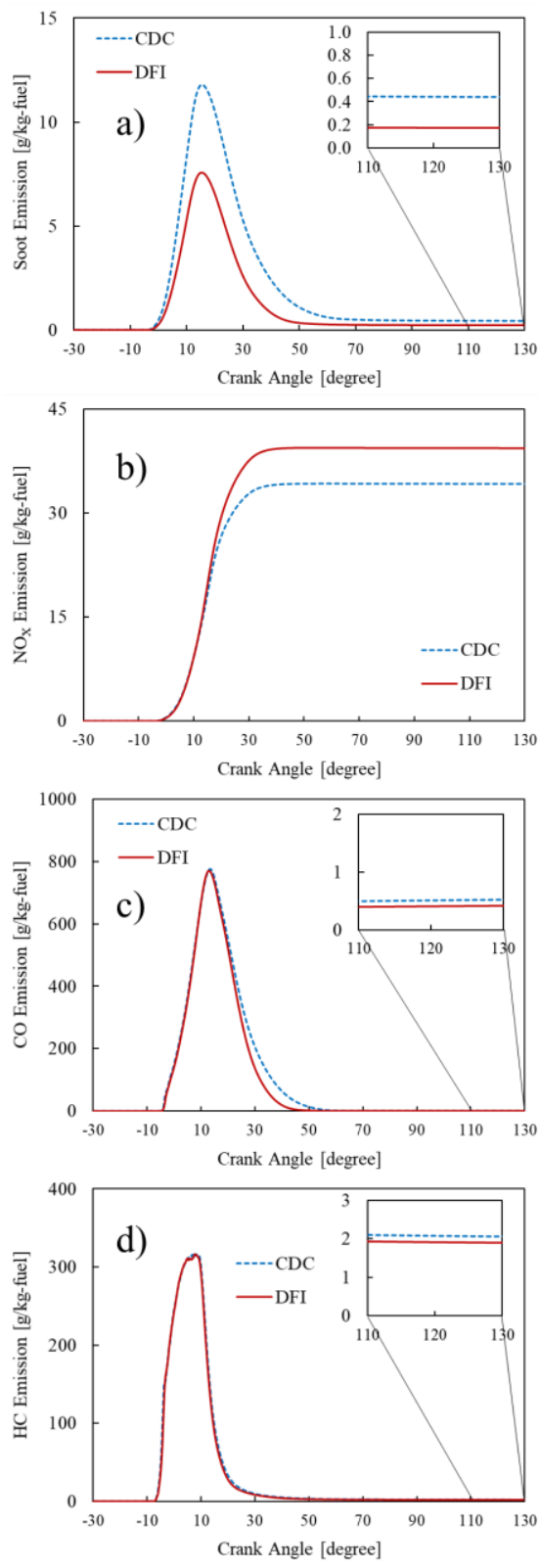

Fig. 11. a) soot, b) $\mathrm{NO}_{\mathrm{x}}$, c) $\mathrm{CO}$, and d) $\mathrm{HC}$ emissions for the CDC and the DFI.

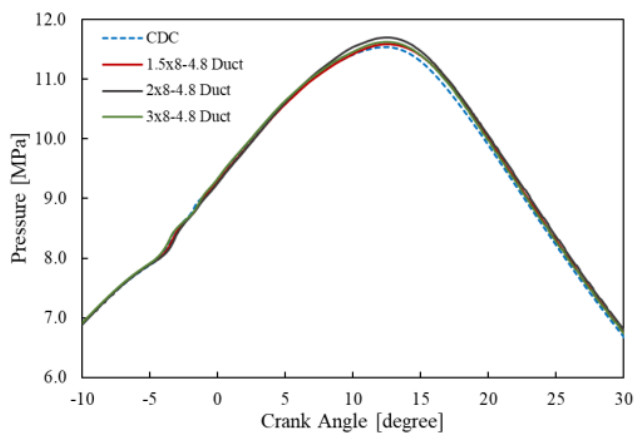

Fig. 12. Comparison of in-cylinder pressure traces for the CDC and three different duct diameters with $8 \mathrm{~mm}$ length and $4.8 \mathrm{~mm}$ axial distance. 


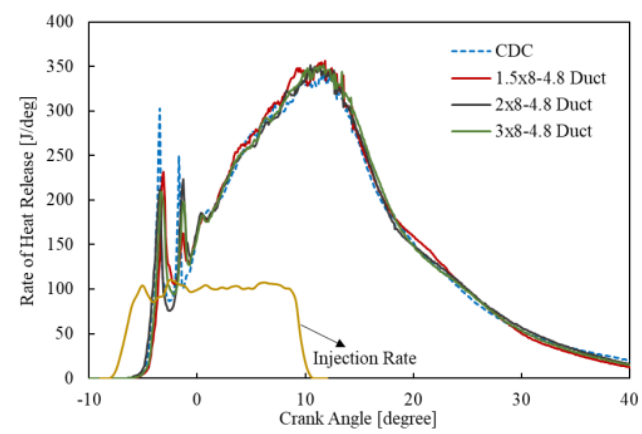

Fig. 13. Comparison of heat release rate for the CDC and three different duct diameters with 8 $\mathrm{mm}$ length and $4.8 \mathrm{~mm}$ axial distance.

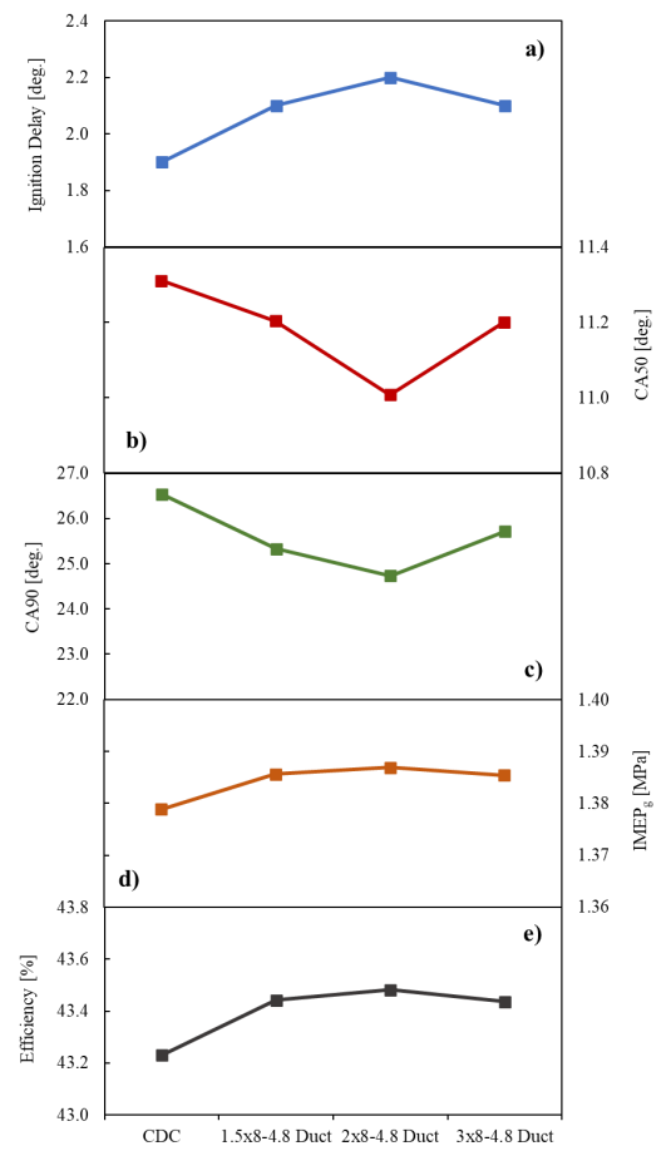

Fig. 14. Comparison of a) ignition delay, b) CA50, c) CA90, d) gross IMEP, e) efficiency for the CDC and three different duct diameter sizes with $8 \mathrm{~mm}$ length and $4.8 \mathrm{~mm}$ axial distance.

Figure 16 shows the distribution of equivalence ratio, soot mass, and temperature of the DFI cases with the varying inner diameter at $11^{\circ}$ ATDC. The equivalence ratio distribution of the $2 \times 8-3.2$ duct is lower around the auto-ignition zone than the $1.5 \times 8$ 4.8 duct and $3 \times 8-4.8$ duct. The soot formation near the bowl walls is visible. As the duct diameter rising, the soot is produced near the duct location. Furthermore, it is observed the temperature increment inside the duct with wider duct diameter.

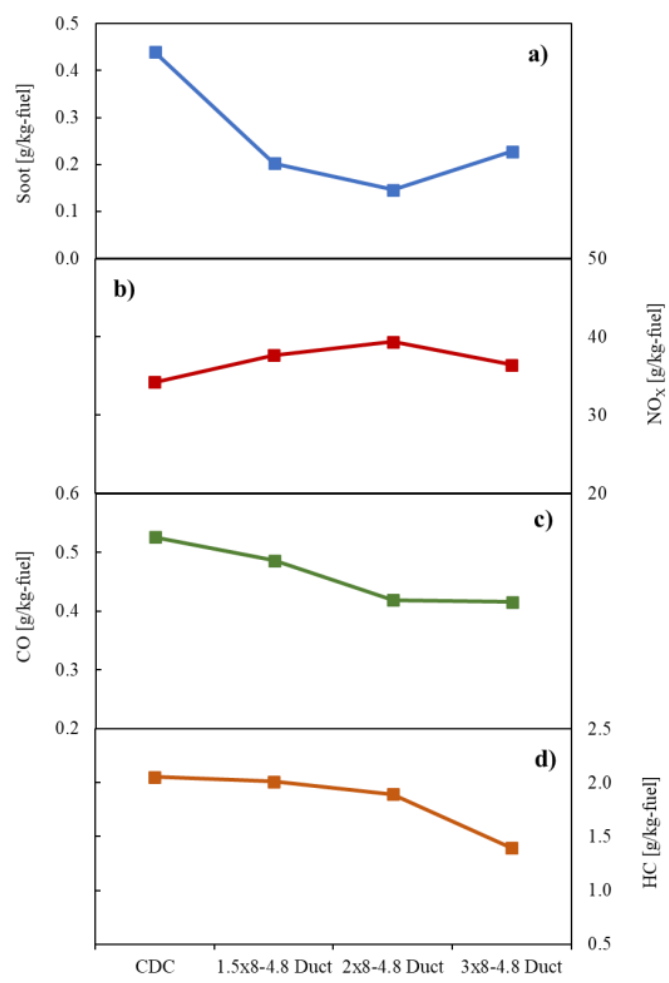

Fig. 15. a) soot, b) $\mathrm{NO}_{\mathrm{x}}$, c) $\mathrm{CO}$, and d) $\mathrm{HC}$ emissions for the CDC and three different duct diameter sizes with $8 \mathrm{~mm}$ length and $4.8 \mathrm{~mm}$ axial distance.

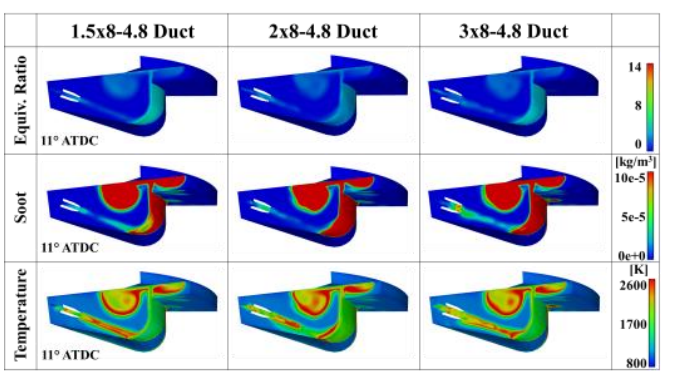

Fig. 16. Equivalence ratio, soot mass, and temperature distributions at $11^{\circ}$ ATDC for the 1.5x8-4.8 duct, $2 \times 8-4.8$ duct, and the $3 \times 8-4.8$ duct.

\subsection{Effect of the duct length}

The effects of duct length have been carried out keeping other parameters constant such as the duct diameter and the stand-off distance. In-cylinder pressure curves of 2x8-3.2 duct, 2x16-3.2 duct, and CDC are illustrated in Fig. 17.

The pressure value of DFI around the maximum pressure zone is higher than $\mathrm{CDC}$ while in-cylinder pressure trends of CDC between $-5^{\circ}$ ATDC and TDC are higher than DFI.

The highest pressure was observed as $11.8 \mathrm{MPa}$ with the $2 \times 16-3.2$ duct. DFI cases have a lower heat release rate during premixed combustion and higher heat release rate during mixing-controlled 


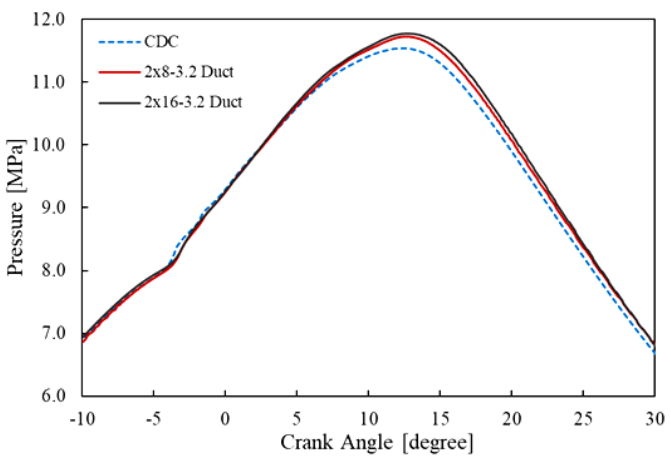

Fig. 17. Comparison of in-cylinder pressure traces for the CDC and two different duct lengths with $2 \mathrm{~mm}$ diameter and $3.2 \mathrm{~mm}$ axial distance.

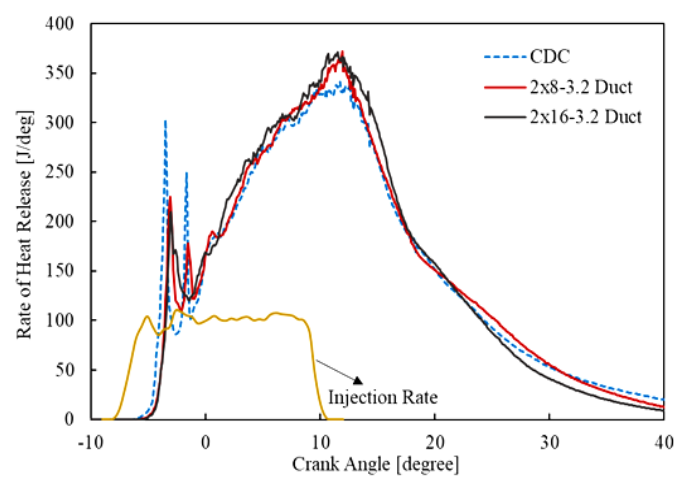

Fig. 18. Comparison of heat release rate for the CDC and two different duct lengths with $2 \mathrm{~mm}$ diameter and $3.2 \mathrm{~mm}$ axial distance.

combustion compared to the CDC. And hence, the production of soot and gross IMEP value is influenced by this situation (Fig. 19). It is shown that with the DFI, the ignition delay is extended. While ignition delay is $1.7^{\circ}$ in CDC, the ignition delays of the $2 \times 8-3.2$ duct and the $2 \times 16-3.2$ duct are $2.3^{\circ}$ and $2.1^{\circ}$, respectively. DFI approach is to shorten the CA50 and CA90. Results show that the highest obtained gross IMEP and indicated thermal efficiency are $1.392 \mathrm{MPa}$ and $43.65 \%$ using the 2x16-3.2 duct (Fig. 19).

Figure 20 illustrates the distribution of equivalence ratio, soot mass, and temperature of the DFI cases with varying duct length at $11^{\circ}$ ATDC. The equivalence ratio of the $2 \times 16-3.2$ duct is higher inside the duct than the $2 \times 8-3.2$ duct. The soot is formed near the walls.

Soot formation decreases noticeably with DFI. While the soot emission decreased by using the duct with different lengths, the maximum reduction was obtained with the $2 \times 8-3.2$ duct as a ratio of $60.5 \%$ (Fig. 21).

$\mathrm{HC}$ and $\mathrm{CO}$ emissions are also significantly reduced with the $2 \times 8-3.2$ duct, while $\mathrm{HC}$ emission increases with the 2x16-3.2 duct. The longer duct length induced higher $\mathrm{HC}$ emissions. $\mathrm{NO}_{\mathrm{x}}$ emissions of the
$2 \times 8-3.2$ duct and the $2 \times 16-3.2$ duct rise by $12.1 \%$ and $27.7 \%$ compared to CDC (Fig. 21). The shortlength duct gives better emission results than the long-length duct.

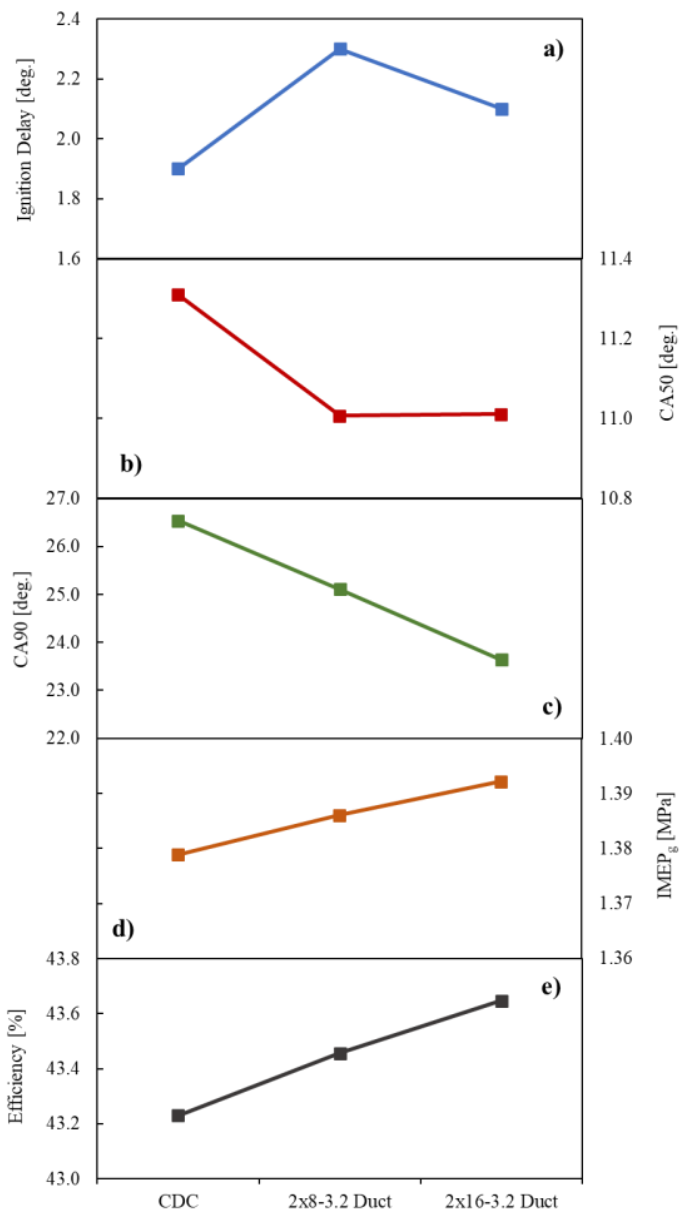

Fig. 19. Comparison of a) ignition delay, b) CA50, c) CA90, d) gross IMEP, e) efficiency for the CDC and two different duct lengths with 2 $\mathrm{mm}$ diameter and $3.2 \mathrm{~mm}$ axial distance.

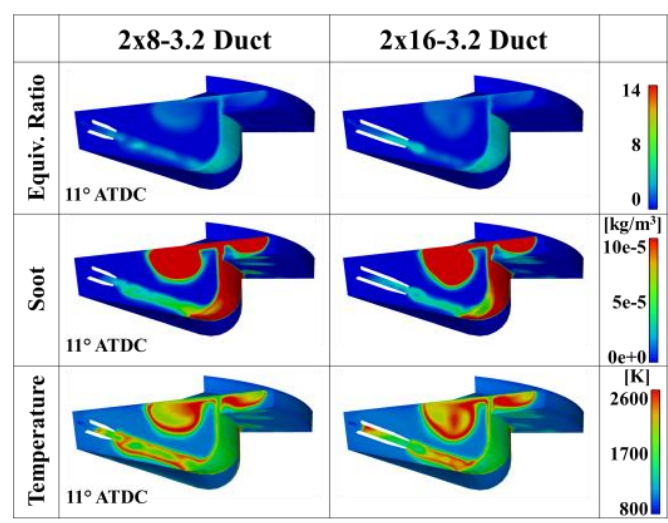

Fig. 20. Equivalence ratio, soot mass, and temperature distributions at $11^{\circ} \mathrm{ATDC}$ for the $2 \times 8-3.2$ duct and the $2 \times 16-3.2$ duct. 


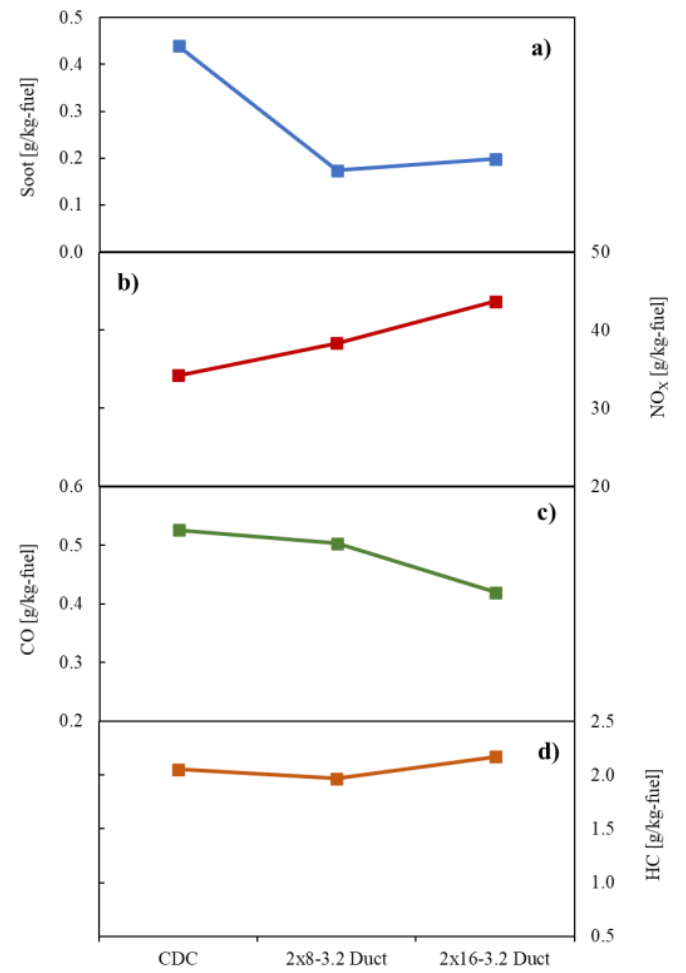

Fig. 21. a) soot, b) $\mathrm{NO}_{\mathrm{x}}$, c) $\mathrm{CO}$, and d) $\mathrm{HC}$ emissions for the CDC and two different duct lengths with $2 \mathrm{~mm}$ diameter and $3.2 \mathrm{~mm}$ axial distance.

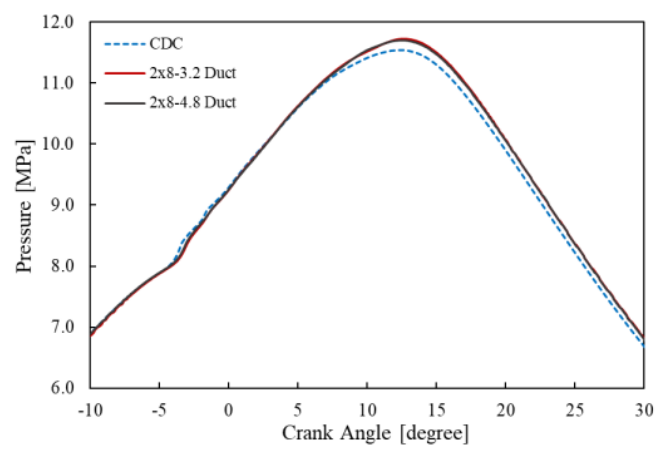

Fig. 22. Comparison of in-cylinder pressure traces for the CDC and two axial distances with $2 \mathrm{~mm}$ diameter and $8 \mathrm{~mm}$ length.

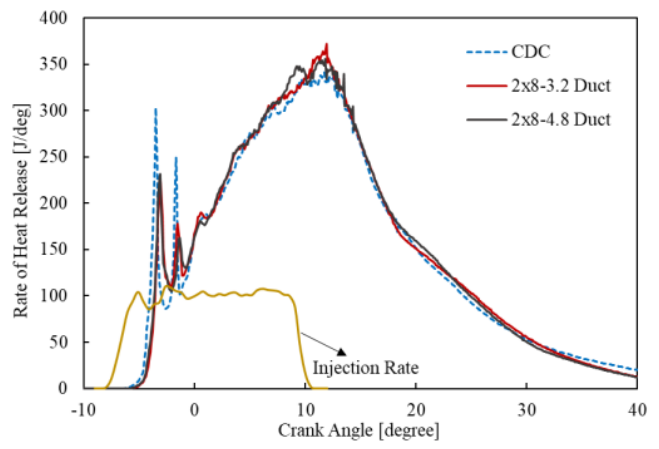

Fig. 23. Comparison of heat release rate for the CDC and two axial distances with $2 \mathrm{~mm}$ diameter and $8 \mathrm{~mm}$ length.

\subsection{Effect of the stand-off distance}

The influence of the stand-off distance of the ducts on the combustion process and emission formation was examined. Two different stand-off distances as $3.2 \mathrm{~mm}$ and $4.8 \mathrm{~mm}$ were used with the diameter of $2 \mathrm{~mm}$ and the duct length of $8 \mathrm{~mm}$. In-cylinder pressure curve of DFI with varying stand-off distance and CDC were compared in Fig. 22. The maximum pressure of $\mathrm{CDC}, 2 \times 8-3.2$, and $2 \times 8-4.8$ ducts were $11.5 \mathrm{MPa}$ at $12.4^{\circ} \mathrm{ATDC}, 11.7 \mathrm{MPa}$ at $12.3^{\circ}$ ATDC, and $11.7 \mathrm{MPa}$ at $12.4^{\circ}$ ATDC, respectively. The premixed combustion phase was decreased with DFI. This impact was clearly seen in the $2 \times 8-4.8$ duct (Fig. 23). Figure 24 depicts the distribution of equivalence ratio, soot mass, and temperature of the DFI cases with different standoff distances at $11^{\circ}$ ATDC. As the equivalence rate drops considerably using the $2 \times 8-4.8$ duct, the soot formation also decreases owing to the LLFC strategy.

Ignition delay increases with DFI as $2.3^{\circ}$ with the 2x8-3.2 duct. Also, CA50 and CA90 extend with DFI. An increase in gross IMEP and engine thermal efficiency is thought to be the response to the changes in these values. Gross IMEP values of the $2 \times 8-3.2$ duct and $2 \times 8-4.8$ duct are $1.386 \mathrm{MPa}$ and 1.387 MPa (Fig. 25).

The highest soot reduction was achieved by using the duct with a stand-off distance of $4.8 \mathrm{~mm}$ at a rate of $66.7 \%$ (Fig. 26). The higher stand-off distance culminated in the lowest reduction in soot emission. However, the combustion chamber geometry limits the maximum value of the stand-off distance of the duct. There was a reduction of up to $20.4 \%$ and $7.8 \%$ in $\mathrm{CO}$ and $\mathrm{HC}$ emissions of $2 \times 8-$ 4.8 duct, respectively. Nevertheless, $\mathrm{NO}_{\mathrm{x}}$ emission rises with $2 \times 8-3.2$ duct and $2 \times 8-4.8$ duct as $12.1 \%$ and $15.1 \%$, respectively. The lowest soot emission was emitted with the $2 \times 8-4.8$ duct.

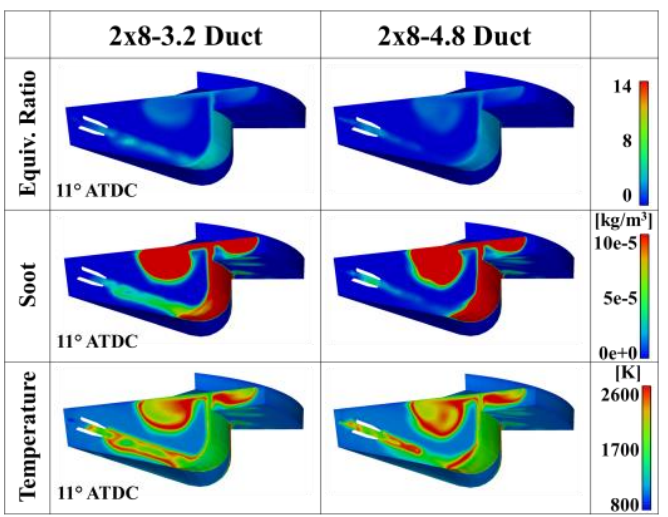

Fig. 24. Equivalence ratio, soot mass, and temperature distributions at $11^{\circ} \mathrm{ATDC}$ for the $2 \times 8-3.2$ duct and the $2 \times 8-4.8$ duct.

\section{CONCLUSION}

The DFI method promises a significant reduction in soot emissions in direct injection CI engines. The 


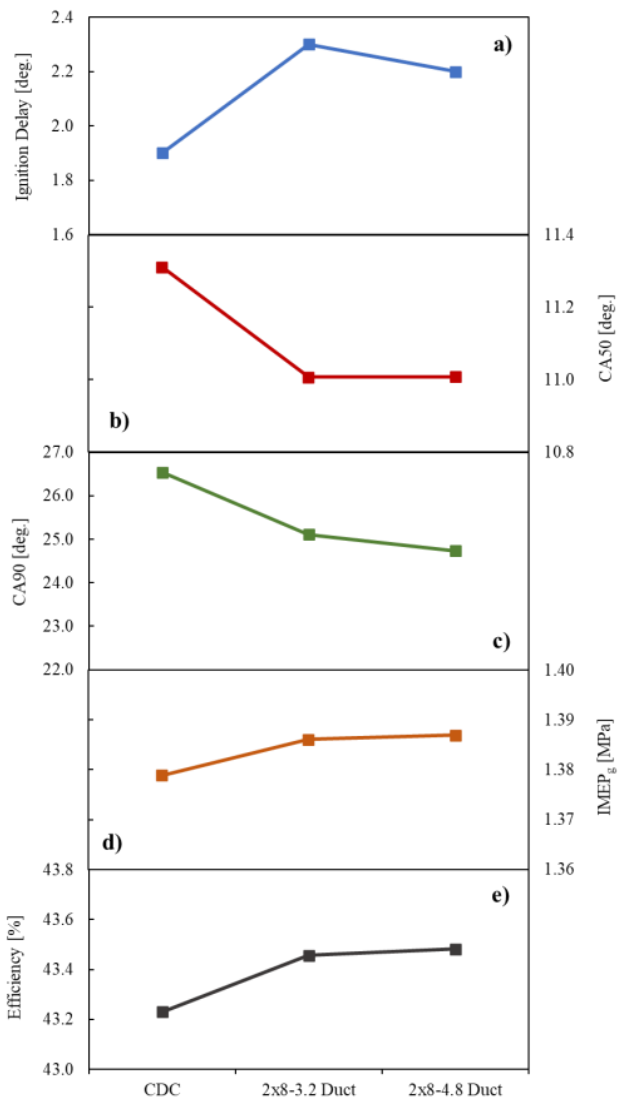

Fig. 25. Comparison of a) ignition delay, b) CA50, c) CA90, d) gross IMEP, e) efficiency for the CDC and two axial distances with $2 \mathrm{~mm}$ diameter and $8 \mathrm{~mm}$ length.

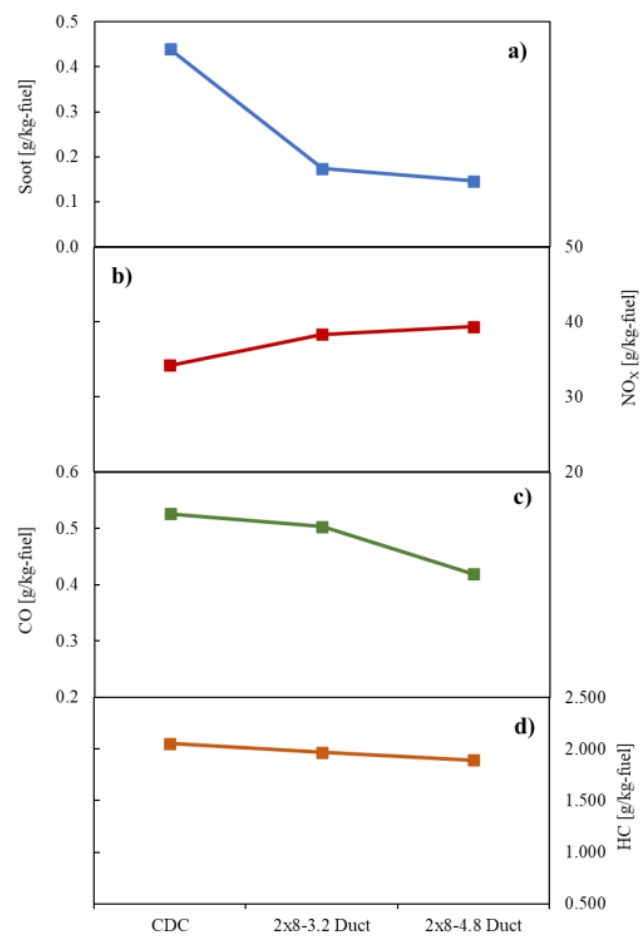

Fig. 26. a) soot, b) $\mathrm{NO}_{x}$, c) $\mathrm{CO}$, and d) $\mathrm{HC}$ emissions for the CDC and two axial distances with $2 \mathrm{~mm}$ diameter and $8 \mathrm{~mm}$ length. fuel-air mixture is improved by injecting the fuel through a duct. It reduces the equivalence ratio of the mixture in the auto-ignition region. It has been stated in past studies that if this ratio can be reduced to less than two, a significant decrease in emissions will be observed. In this study, the effectiveness of the DFI strategy was investigated by using an experimentally validated engine model. The influence of three main geometric parameters of the duct geometry as diameter, length, and stand-off distance on the combustion and emission were investigated. In all DFI cases with different diameters, lengths, and stand-off distances, improvement in soot emissions has been observed compared to CDC. This study demonstrates the great potential of a basic, simple, and mechanical novel device in reducing soot emissions. The adaptation of this device into the combustion chamber is limited by engine dimensions piston, and valve movements. It is understood that even for light-duty engines and small duct dimensions are used, and the strategy will preserve its effectiveness. The main findings of this study are listed below:

1. Soot emission of up to $66.7 \%$ was achieved with the DFI approach using the $2 \times 8-4.8$ duct compared to CDC under the same operating conditions. The most effective duct for this engine was the diameter of $2 \mathrm{~mm}$, the length of $8 \mathrm{~mm}$, and the axial distance of $4.8 \mathrm{~mm}$.

2. Soot emission has decreased more or less compared to CDC with all applied geometric parameters. An emission reduction of $48.1 \%$ was achieved with the $3 \times 8-4.8$ duct, which is emitted the highest soot emission among all ducted cases.

3. $\mathrm{NO}_{\mathrm{x}}$ emissions increase between $6 \%$ and $27 \%$ using the DFI method, but the gross IMEP values increase.

4. DFI method increases the ignition delay and decreases the combustion duration. It is understood that these alterations in the combustion process are the one reason for the decrease in soot emissions.

5. $\mathrm{HC}$ and $\mathrm{CO}$ emissions are also diminished with the DFI strategy in some cases.

In future work, the duct geometrical parameters will be optimized using a genetic algorithm method. Thus, the most suitable design can be determined, and the DFI strategy can be used in the most effective way. The effects of the piston bowl design will be investigated on combustion and emission. Different load and spray properties will be examined in order to achieve the LLFC strategy. Moreover, EGR will be applied to control NOx emissions and tried to decrease in parallel with soot emissions. It will be investigated the potential of the DFI method to break the soot-NOx trade-off.

\section{ACKNOWLEDGMENT}

The author (R. Şener) gratefully acknowledges Convergent Science Inc. for providing the Converge license. 


\section{REFERENCES}

Ahmed, S. S., F. Mauß, G. Moréac and T. Zeuch (2007). A comprehensive and compact nheptane oxidation model derived using chemical lumping. Physical Chemistry Chemical Physics 9(9), 1107-1126.

Amsden, A. A. (1997). KIVA-3V: A BlockStructured KIVA Program for Engines with Vertical or Canted Valves. In LA Report. Los Alamos National Laboratory, 1-75.

An, Y., M. Jaasim, V. Raman, F. E. Hernández Pérez, J. Sim, J. Chang, H. G. Im and B. Johansson (2018). Homogeneous charge compression ignition (HCCI) and partially premixed combustion (PPC) in compression ignition engine with low octane gasoline. Energy 158, 181-191.

Babayev, R., A. Andersson, A. S. Dalmau, H. G. Im and B. Johansson (2021). Computational characterization of hydrogen direct injection and nonpremixed combustion in a compression-ignition engine. International Journal of Hydrogen Energy 46(35), 1867818696.

Bakhshan, Y. and A. H. Shadaei (2013). QuasiDimensional Modeling of a CNG Fueled HCCI Engine Combustion Using Detailed Chemical Kinetic. Journal of Applied Fluid Mechanics 6(2), 239-247.

Beale, J. C. and R. D. Reitz (1999). Modeling spray atomization with the KelvinHelmholtz/Rayleigh-Taylor hybrid model. Atomization and Sprays 9(6), 623-650..

Brijesh, P. and S. Sreedhara (2013). Exhaust emissions and its control methods in compression ignition engines: A review. International Journal of Automotive Technology 14(2), 195-206.

Calam, A., H. Solmaz, E. Yılmaz and Y. İçingür (2019). Investigation of effect of compression ratio on combustion and exhaust emissions in A HCCI engine. Energy 168(1), 1208-1216.

Curran, H. J., P. Gaffuri, W. J. Pitz and C. K. Westbrook (1998). A Comprehensive Modeling Study of n-Heptane Oxidation. Combustion and Flame 114(1), 149-177.

Curtis, E. W., A. Uludogan and R. D. Reitz (1995). A New High Pressure Droplet Vaporization Model for Diesel Engine Modeling. SAE Technical Papers 412, 1-13.

De Soete, G. G. (1975). Overall reaction rates of $\mathrm{NO}$ and $\mathrm{N} 2$ formation from fuel nitrogen. International Symposium on Combustion 15(1), 1093-1102.

Deb, M., A. Paul, D. Debroy, G. R. K. Sastry, R. S. Panua and P. K. Bose (2015). An experimental investigation of performanceemission trade off characteristics of a $\mathrm{CI}$ engine using hydrogen as dual fuel. Energy $85,569-585$.

Demirkesen, C., U. Colak, I. H. Savci and H. B. Zeren (2020). Experimental and Numerical Investigation of Air Flow Motion in Cylinder of Heavy Duty Diesel Engines. Journal of Applied Fluid Mechanics 13(2), 537-547.

Fajri, H. R., A. H. Shamekhi, S. Rezaie, M. J. Jafari and S. A. Jazayeri (2019). A Detailed Study of Boost Pressure and Injection Timing on an RCCI Engine Map Fueled with Iso-Octane and N-Heptane Fuels. Journal of Applied Fluid Mechanics 12(4), 1161-1175.

Fitzgerald, R. P., K. Svensson, G. Martin, Y. Qi and C. Koci (2018). Early Investigation of Ducted Fuel Injection for Reducing Soot in Mixing-Controlled Diesel Flames. SAE International Journal of Engines 11(6), 817833.

Galindo, J., S. Hoyas, P. Fajardo and R. Navarro (2013). Set-Up Analysis and Optimization of CFD Simulations for Radial Turbines. Engineering Applications of Computational Fluid Mechanics 7(4), 441-460.

Gandhi, H. S., G. W. Graham and R. W. McCabe (2003). Automotive exhaust catalysis. Journal of Catalysis 216(1-2), 433-442.

Gehmlich, R. K., C. E. Dumitrescu, Y. Wang and C. J. Mueller (2016). Leaner Lifted-Flame Combustion Enabled by the Use of an Oxygenated Fuel in an Optical CI Engine. SAE International Journal of Engines 9(3), 1526-1543.

Gehmlich, R. K., C. J. Mueller, D. J. Ruth, C. W. Nilsen, S. A. Skeen and J. Manin (2018). Using ducted fuel injection to attenuate or prevent soot formation in mixing-controlled combustion strategies for engine applications. Applied Energy 226, 11691186.

Gugulothu, S. K. and K. H. C. Reddy (2016). CFD Simulation of In-Cylinder Flow on Different Piston Bowl Geometries in a DI Diesel Engine. Journal of Applied Fluid Mechanics 9(3), 1147-1155.

Han, Z. and R. D. Reitz (1995). Turbulence Modeling of Internal Combustion Engines Using RNG k-ع Models. Combustion Science and Technology 106(1), 267-295.

Heywood, J. (1988). Internal combustion engine fundamentals. In McGraw Hill.

Ibrahim, F., W.M.F. Wan Mahmood, S. Abdullah and M.R.A. Mansor (2017). Comparison of Simple and Detailed Soot Models in the Study of Soot Formation in a Compression Ignition Diesel Engine. SAE Technical Papers 2017-01-10, 1-9.

Knecht, W. (2008). Diesel engine development in view of reduced emission standards. Energy 
33(2), 264-271

Kumar, S. and D. Ramkrishna (1996). On the solution of population balance equations by discretization-II. A moving pivot technique. Chemical Engineering Science 51(8), 13331342.

Lao, C. T., J. Akroyd, N. Eaves, A. Smith, N. Morgan D. Nurkowski, A. Bhave and M. Kraft (2020). Investigation of the impact of the configuration of exhaust after-treatment system for diesel engines. Applied Energy 267,114844 .

Li, F., C. Lee, Z. Wang, F. Liu and G. Lu (2020). Optical investigation on impacts of ambient pressure on macroscopic spray characteristics of ducted fuel injection under non-vaporizing conditions. Fuel 268, 117192.

Li, F., C. Lee, Z. Wang, Y. Pei and G. Lu (2021). Impacts of duct inner diameter and standoff distance on macroscopic spray characteristics of ducted fuel injection under non-vaporizing conditions. International Journal of Engine Research 22(5), 1702-1713.

Li, F., C. Lee, H. Wu, Z. Wang and F. Liu (2019). An optical investigation on spray macroscopic characteristics of ducted fuel injection. Experimental Thermal and Fluid Science 109, 109918.

Liu, X., B. Mohan and H. G. Im (2020). Numerical Investigation of the Free and Ducted Fuel Injections under Compression Ignition Conditions. Energy \& Fuels 34(11), 1483214842 .

Manuel, A., D. Gonzalez, G. L. Borman and R. D. Reitz (1991). A study of diesel cold starting using both cycle analysis and multidimensional calculations. SAE International Journal of Engines, 100(3), 189-208.

Mathivanan, K., J. M. Mallikarjuna and A. Ramesh (2019). Effect of Timing and Pattern of Fuel Injection on Performance and Emissions of a Diesel Engine in the Low-Temperature Combustion Mode - An Experimental Investigation. Journal of Applied Fluid Mechanics 12(6), 1769-1780.

Mofijur, M., M. M. Hasan, T. M. I. Mahlia, S. M. A. Rahman, A. S. Silitonga and H. C. Ong (2019). Performance and Emission Parameters of Homogeneous Charge Compression Ignition (HCCI) Engine: A Review. Energies 12(18), 3557.

Mohan, B., W. Yang and S. K. Chou (2013). Fuel injection strategies for performance improvement and emissions reduction in compression ignition engines-A review. Renewable and Sustainable Energy Reviews 28, 664-676.

Mueller, C. J., C. W. Nilsen, D. J. Ruth, R. K. Gehmlich, L. M. Pickett and S. A. Skeen
(2017). Ducted fuel injection: A new approach for lowering soot emissions from direct-injection engines. Applied Energy 204, 206-220.

Nilsen, C. W., D. E. Biles and C. J. Mueller (2019). Using Ducted Fuel Injection to Attenuate Soot Formation in a Mixing-Controlled Compression Ignition Engine. SAE International Journal of Engines 12(3), 3-12.

Nilsen, C. W., D. E. Biles, B. F. Yraguen and C. J. Mueller (2020). Ducted Fuel Injection versus Conventional Diesel Combustion: An Operating-Parameter Sensitivity Study Conducted in an Optical Engine with a FourOrifice Fuel Injector. SAE International Journal of Engines 13(3), 1-18.

Pickett, L. M. (2005). Low flame temperature limits for mixing-controlled Diesel combustion. Proceedings of the Combustion Institute 30(2), 2727-2735.

Polonowski, C. J., C. J. Mueller, C. R. Gehrke, T. Bazyn, G. C. Martin and P. M. Lillo (2011). An Experimental Investigation of Low-Soot and Soot-Free Combustion Strategies in a Heavy-Duty, Single-Cylinder, DirectInjection, Optical Diesel Engine. SAE International Journal of Fuels and Lubricants 5(1), 51-77.

Praveena, V. and M. L. J. Martin (2018). A review on various after treatment techniques to reduce NOx emissions in a $\mathrm{CI}$ engine. Journal of the Energy Institute 91(5), 704720 .

Reitz, R.D. (1987). Mechanisms of Atomization Processes in High-Pressure Vaporizing Sprays. Atomization and Spray Technology 3, 309-337.

Reitz, R. D., H. Ogawa, R. Payri, T. Fansler, S. Kokjohn, Y. Moriyoshi, A. Agarwal, D. Arcoumanis, D. Assanis, C. Bae, K. Boulouchos, M. Canakci, S. Curran, I. Denbratt, M. Gavaises, M. Guenthner, C. Hasse, Z. Huang, T. Ishiyama ... H. Zhao (2020). IJER editorial: The future of the internal combustion engine. International Journal of Engine Research 21(1), 3-10.

Richards, K. J., P. K. Senecal and E. Pomraning (2019). CONVERGE 2.4 Manual (p. 1078). Convergent Science.

Schmidt, D. P. and C. J. Rutland (2000). A New Droplet Collision Algorithm. Journal of Computational Physics 164(1), 62-80.

Senecal, P. K., E. Pomraning, K. J. Richards, T. E. Briggs, C. Y. Choi, R. M. Mcdavid and M. A. Patterson (2003). Multi-Dimensional Modeling of Direct-Injection Diesel Spray Liquid Length and Flame Lift-off Length using CFD and Parallel Detailed Chemistry. SAE International Journal of Engines, 112(3), 1331-1351. 
Senecal, P. K., K. J. Richards, E. Pomraning, T. Yang, M. Z. Dai, R. M. McDavid, M. A. Patterson, S. Hou and S. T. hethaji (2007). A new parallel cut-cell cartesian CFD code for rapid grid generation applied to in-cylinder diesel engine simulations. SAE Technical Papers, 1-32.

Şener, R. and M. Z. Gül (2021). Optimization of the combustion chamber geometry and injection parameters on a light-duty diesel engine for emission minimization using multi-objective genetic algorithm. Fuel 304, 121379.

Sener, R., M. U. Yangaz and M. Z. Gul (2020). Effects of injection strategy and combustion chamber modification on a single-cylinder diesel engine. Fuel 266(1), 117122.

Sherwood, A. (1993). Los Alamos National Laboratory ion implantation program with General Motors and the University of Wisconsin. Journal of Fusion Energy 12(4), 405-405.

Svensson, K. I. and G. C. Martin (2019). Ducted Fuel Injection: Effects of Stand-Off Distance and Duct Length on Soot Reduction. SAE Technical Papers 4, 1-10.

Turkcan, A., A. N. Ozsezen, M. Canakci, G. Coskun, H. S. Soyhan and U. Demir (2015). An Experimental and Modeling Study to Investigate Effects of Two-Stage Direct Injection Variations on HCCI Combustion. Combustion Science and Technology 187(4), 642-658.

Vadivel, A. and S. Periyasamy (2020). Experimental Investigation of Thermal Barrier (8YSZ-MGO-TIO2) Coated Piston used in Diesel Engine. Journal of Applied Fluid Mechanics 13(4), 1157-1165.

Walters, R. (2010). Toxic Atmospheres Air
Pollution, Trade and the Politics of Regulation. Critical Criminology 18(4), 307323.

Wen, J. Z., M. J. Thomson, S. H. Park, S. N. Rogak and M. F. Lightstone (2005). Study of soot growth in a plug flow reactor using a moving sectional model. Proceedings of the Combustion Institute 30(1), 1477-1484.

Yakhot, V. and S. A. Orszag (1986). Renormalization group analysis of turbulence: I. Basic theory. Journal of Scientific Computing 1(1), 3-51.

Yangaz, M. U., G. A. Çiftçioğlu and M. A. N. Kadırgan (2019). Comparison of Conventional and Modified Burners in Performance with Different Fuels using a Linear and a Non-linear Eddy-viscosity Turbulence Model. Journal of Applied Fluid Mechanics 12(6), 2069-2081.

Yousefi, A., H. Guo and M. Birouk (2020). Split diesel injection effect on knocking of natural gas/diesel dual-fuel engine at high load conditions. Applied Energy 279, 115828.

Zeuch, T., G. Moréac, S. S. Ahmed and F. Mauss (2008). A comprehensive skeletal mechanism for the oxidation of n-heptane generated by chemistry-guided reduction. Combustion and Flame 155(4), 651-674.

Zhou, L., M. D. Boot, B. H. Johansson and J. J. E. Reijnders (2014). Performance of lignin derived aromatic oxygenates in a heavy-duty diesel engine. Fuel 115, 469-478.

Zhu, J., K. O. Lee, A. Yozgatligil and M. Y. Choi (2005). Effects of engine operating conditions on morphology, microstructure, and fractal geometry of light-duty diesel engine particulates. Proceedings of the Combustion Institute 30(2), 2781-2789. 